\title{
George Goudie Chisholm, M.A., B.Sc., LL.D.
}

George Goudie Chisholm was born in Edinburgh on 1st May 1850, educated at the High School, which he left as Dux, and at the University, where he took a good place in the Arts classes and graduated M.A. in 1870. With a natural gift for languages he soon added to his knowledge of Latin and Greek a practical acquaintance with French, German, and Italian. $\mathrm{He}$ entered on a literary career in the editorial department of W. G. Blackie \& Son of Glasgow, where he developed an innate bent towards accurate and methodical work by taking part in the revision of the famous Imperial Dictionary. Yielding to the traditional southward urge Chisholm went to London in 1881, and this was his home for more than a quarter of a century. He took the Edinburgh degree of B.Sc. in natural sciences, however, in 1883. Chisholm specialized in Geography, became a University Extension Lecturer in London, and built for himself an enduring reputation in his chosen subject.

In 1908, when Edinburgh established a Lectureship on Geography, the first in any Scottish University, Chisholm was the obvious choice as Lecturer, and in 1921, when the academic grade was sanctioned, he became Reader. After his retirement in $\mathbf{1 9 2 3}$ he received the honorary degree of LL.D. from his own University. Freed from routine duties, Dr Chisholm continued to work upon the problems to which he had devoted his life, and death overtook him suddenly and painlessly on 9th February 1930.

Few men of his intellectual power and ceaseless industry have led a life so quiet and uneventful as that which fell to his lot. He worked at home, and both in London and in Edinburgh his wife regulated the routine of the house so as to ensure for him the orderly quiet and seclusion which were his proper environment.

In 1882 Chisholm published his first geographical work, a popular description of the Earth, under the title of The Two Hemispheres. It was a sincere and well-proportioned compilation of the best data then available. The Royal Geographical Society, which for fifty years had viewed the encouragement of exploration as its chief purpose, was awakening about that time to a sense of the deplorable neglect of Geography in Great Britain. No university looked on it as worthy of academic recognition; there were few text-books suitable for school use, and such as existed were unscientific in arrangement and inaccurate in their reproduction of the obsolescent sources they drew upon. 
When in 1884 Sir John Scott Keltie issued his epoch-marking Report on the State of Geographical Education and threw into vivid contrast the status of Geography in the continental universities and schools and in our own, Chisholm, already prepared for the task, was the first amongst his countrymen to make the advancement of Geography in education the business of his life. He began by producing a series of school geographies for Messrs Longmans which adapted to the conditions of Great Britain and of the different Dominions the principles of the best German Lehrbiicher. He went on to produce a School Atlas which set a new standard in simplicity, consistency, and the accuracy which depends on truth to scale rather than on minute detail. These pioneer works were a noble contribution to intelligent teaching.

Chisholm's masterpieces, however, were of a much more ambitious character. The first was his massive Handbook of Commercial Geography, first published in 1889 , when there was hardly yet a public fit to profit by its strong handling of an infinity of authoritative detail. As the years passed, appreciation and demand grew together, and when, two years ago, the eleventh edition appeared, the work had come to be recognised as a classic far beyond the English-speaking world-an Arabic translation published in Cairo attests this.

His other magnum opus is the impressive one-volume Gazetteer of the World published by Longmans in 1895 and very widely disseminated some years later as The Times Gazetteer. It is full and detailed, but so well proportioned in its entries as to remain clear and concise. Its accuracy is amazing, and only the concentration of a disciplined mind could have brought a chaos of isolated facts into such harmonious order.

Chisholm brought the logical powers which made him great as a compiler to bear with equal success on original geographical problems. Good examples are his memoirs on the "Distribution of Towns and Villages in England" and on "Inland Waterways" published in the Geographical Journal. He was a regular attendant at the meetings of the British Association, and read many papers to Section E, including the Presidential Address in 1907. As time went on he turned his attention mainly to questions of economic distribution and racial peculiarities. At the end of his life he was engaged on the elaboration of an original system which he termed Economic Ethnography, by means of this he hoped to apply geographical principles to current human problems.

As a teacher Chisholm did not court popularity by cheapening the intellectual price which must be paid for proficiency. He insisted on thoroughness and accuracy at every stage of his university courses, and the 
serious student drew from him an inspiration surprising as coming from a man of such quiet and unemotional demeanour. Those who met Dr Chisholm in the University or in the Royal Scottish Geographical Society, of which he was long the Secretary, respected him for his learning, his modesty, and his readiness to help. Apart from the honorary degree of his own University and the gold medals of American Geographical Societies, he did not receive in his lifetime the honours to which his attainments entitled him; but he permitted no bitterness to shadow his well-balanced outlook on life. $\mathrm{He}$ was a generous colleague, ever ready to help a rival as a friend, and the few who penetrated the guard of his meticulous precision recognized him as a man of wide sympathies and liberal culture. His knowledge of Shakespeare was remarkable, and few of his academic acquaintances detected from his conversation the enjoyment he derived from the works of the great Victorian poets.

To whatever test it may be put, the memory of Chisholm rings true as that of a man absolutely sincere, strong in the conscientious fulfilment of every duty, steadfast in purpose, but undisturbed by ambition.

He was elected a Fellow in 1924.

H. R. M. 